\title{
Nas trincheiras do front intelectual \\ Henrique da Rocha Lima e a Primeira Guerra Mundial no Jornal do Commercio
}

\section{In the Trenches of the Intellectual Front}

Henrique da Rocha Lima and the First World War in the Jornal do Commercio

André Felipe Cândido da Silva

Casa de Oswaldo Cruz

Fundação Oswaldo Cruz

Av. Brasil 4036, $4^{\circ}$ andar, s. 420, Manguinhos, Rio de Janeiro, RJ, 21.040-361, Brasil andre.silva@fiocruz.br

Resumo $\mathrm{O}$ artigo explora os textos publicados pelo pesquisador brasileiro Henrique da Rocha Lima no Jornal do Commercio no primeiro ano da 'Grande Guerra'. Ele escreveu suas impressões de Hamburgo, de onde afirmou obter informações de primeira mão com as quais buscou contrariar ou problematizar as notícias divulgadas pelas agências francesa e inglesa. A propaganda aliada encontrou fértil terreno no Brasil, no que foi favorecida pela francofilia de nossas elites. O pesquisador brasileiro procurou combater a ideia de que a Alemanha era a causadora da Guerra, além de desmentir o que via como calúnias e mentiras veiculadas pelos aliados, como notícias das barbáries cometidas pelos alemães em território inimigo. $\mathrm{O}$ engajamento de Rocha Lima foi na contramão das tendências do mundo letrado e científico brasileiro, em sua grande parte simpáticos à causa Aliada, além de representar perfil de atuação pública que se tornaria a marca de sua trajetória profissional. Palavras-chave Primeira Guerra Mundial, Henrique da Rocha Lima, imprensa

Recebido: 27 de fevereiro de 2015 | Aprovado: 02 de julho de 2015

http://dx.doi.org/10.1590/0104-87752015000300002

Varia Historia, Belo Horizonte, vol. 31, n. 57, p. 635-671, set/dez 2015 
Abstract This article discusses texts published by the Brazilian researcher Henrique da Rocha Lima in the Jornal do Commercio during the first year of the "Great War". Rocha Lima wrote his impressions from Hamburg, where he said he had first-hand information with which sought to discuss reports by French and British agencies. The Allied propaganda found a fertile ground in Brazil, which was favored by the francophile of our elites. The Brazilian researcher combated the idea that Germany was causing the war, and denied what he saw as calumny and lies spread by the allies, as news about the atrocities committed by the Germans in enemy territory. Rocha Lima's engagement was in the opposite trends of the Brazilian scholars and scientific world, for the most part friendly to the Allied cause, what also represents his public profile that would become the hallmark of his career.

KEYwORDs First World War, Henrique da Rocha Lima, press

A mobilização dos intelectuais em favor de um dos lados beligerantes na Primeira Guerra foi quase tão célere e intenso quanto aquele que conduziu milhares de cidadãos ao front. No Brasil não foi diferente. A imprensa foi um dos principais campos em que se esgrimiram argumentos e desenrolaram-se controvérsias em relação ao conflito. Além dos jornais, as conferências, associações intelectuais e ligas surgidas em decorrência da guerra também foram espaços nos quais os intelectuais engajaram-se "na cristalização e na difusão de representações de uma guerra que abrasa o que eles então consideram como o coração do mundo civilizado" (Compagnon, 2014, p.67). De acordo com Maria Inés Tato "os intelectuais atuaram na qualidade de guias e orientadores da opinião pública, à qual ofereceram leituras divergentes da delicada situação internacional, filiadas aos modelos culturais que haviam conformado sua formação profissional” (2012, p.206).

No Brasil, a batalha de ideias e paixões entre os favoráveis à Tríplice Entente - chamados de aliadófilos - e os inclinados em favor das potências centrais - os germanófilos - foi bem mais desequilibrada do que no front. A maior parte dos veículos posicionou-se a favor da França, 
Inglaterra e Rússia, impelidos pelos laços econômicos com o império britânico e de identificação cultural, que atavam os intelectuais e as elites brasileiras à primeira. Aliadofilia foi praticamente francofilia (Luebke, 1987, p.84-85; Compagnon, 2014). Assim como os alemães, os imigrantes italianos expressaram-se em favor de seu país de origem, um aliado dos impérios de Guilherme II e dos Habsburgo, mas que em 1915 entrou na Guerra ao lado da Tríplice Entente devido a interesses territoriais que o opunham à Áustria-Hungria (Luebke, 1987, p.84). A França, identificada como o berço da civilização, da ordem democrática e republicana, das luzes, das letras e das artes ganhou ascendência nos corações e mentes dos intelectuais e publicistas brasileiros. Por outro lado, a maior parte dos jornais era abastecida de notícias internacionais por meio das agências Havas - francesa - e Reuters - inglesa. Estas dedicaram-se a divulgar relatos e impressões favoráveis aos Aliados, numa tentativa de modelar as percepções do conflito entre os que o acompanhavam de longe.

No presente trabalho vou tratar de um personagem que remou na contracorrente dessa tendência: o médico brasileiro Henrique da Rocha Lima (1879-1956), que desde 1909 atuava no Instituto de Doenças Marítimas e Tropicais de Hamburgo. A deflagração da guerra surpreendeu Rocha Lima e o colega do mesmo instituto, Stanislas von Prowazek, no retorno de Constantinopla à cidade hanseática. Na capital do império otomano, eles investigaram surto de tifo exantemático surgido em decorrência das guerras balcânicas (Silva, 2011). Pouco depois do início do conflito, o pesquisador brasileiro escreveu uma série de artigos em favor da Alemanha no Jornal do Commercio, um dos veículos de maior circulação no Rio de Janeiro, então capital federal. O objetivo aqui é analisar os principais argumentos apresentados pelo médico brasileiro, a visão que ele nutriu da Guerra e as controvérsias geradas no ambiente intelectual da época. Pretendo comparar tais argumentos com aqueles expostos por intelectuais germanófilos na Argentina, onde a corrente pró-Alemanha foi bem mais significativa do que no Brasil. O engajamento de Rocha Lima e desses intelectuais em favor de um dos lados em confronto foi produto das circunstâncias inauguradas pela chamada 
"Grande Guerra", na qual os homens de ciência e de letras empunharam suas penas, estendendo as batalhas ao mundo letrado.

Nascido no Rio de Janeiro em 24 de novembro de 1879, Henrique da Rocha Lima participou da criação de uma das principais instituições dedicadas à medicina experimental e à produção de vacinas e produtos biológicos da época: o Instituto de Manguinhos, a partir de 1908 renomeado Instituto Oswaldo Cruz. Entre 1901 e 1903 especializou-se na Alemanha, ficando deslumbrado com a sociedade, cultura e ciência alemãs e iniciando-se aí uma identificação que marcaria toda sua trajetória e identidade profissional (Silva, 2011). As ligações da medicina brasileira com a alemã no início do século XX eram densas, sobretudo no terreno da medicina experimental (Silva, 2011; Benchimol, 2013). Em 1908, ano em que o Instituto Soroterápico Federal em Manguinhos tornouse Instituto de Medicina Experimental, pesquisadores do Instituto de Doenças Marítimas e Tropicais de Hamburgo passaram uma temporada na instituição brasileira a oferecer cursos, treinar pesquisadores e realizar pesquisas (Benchimol, 1990; Sá, 2005). No ano seguinte, um desses visitantes, o já referido Stanislas von Prowazek, convidou Rocha Lima para ingressar no Instituto de Hamburgo, no qual este permaneceu até 1927, quando então retornou ao Brasil, onde veio a falecer em 1956.

Segundo Rocha Lima, a iniciativa de publicar textos pró-Alemanha na imprensa brasileira partira dele próprio. Justificou-a pela necessidade de desmentir a "campanha de inverdades, intrigas e calúnias, motivadas pela inveja, ressentimento e preocupação com o rápido progresso da Alemanha" (Rocha Lima, 11.10.1914 [20.08.1914]). ${ }^{1}$ Achava urgente contrabalançar as visões dominantes divulgadas pelas agências francesa e inglesa, cujo monopólio foi bastante favorecido pela interrupção das comunicações telegráficas submarinas da Alemanha com a América Latina pelos ingleses. Além de cortar o cabo que ligava Emden, na Alemanha, a

1 ROCHA LIMA, Henrique da. Da Allemanha - Hamburgo. Jornal do Commercio (Rio de Janeiro), p.4, 11 out. 1914. Entre colchetes, a data que Rocha Lima registrou no texto. Versões datilografadas dos artigos publicados no Jornal do Commercio e com a data original encontram-se no fundo pessoal do cientista, sob a guarda do Centro de Memória do Instituto Biológico de São Paulo. 
Pernambuco, os ingleses preveniram a comunicação por navios através do bloqueio naval (Luebke, 1987, p.90). Os artigos de Rocha Lima só puderam alcançar o Brasil porque eram remetidos na forma de cartas, provavelmente através de emissários que cruzavam o Atlântico nos dois sentidos. Para o cônsul alemão em Porto Alegre, Freiherr von Stein, um personagem ativo na tentativa de contrabalançar a propaganda francesa e inglesa e de neutralizar a campanha contra os alemães e teuto-brasileiros, "sementes lançadas pelo consórcio Havas, que antes já eram ervas daninhas em crescimento, agora, durante a Guerra, brotam da forma mais exuberante possível”. "Contra estas armas, que constituem motivo único do sucesso inigualável da corrente germanófoba agora observada está a Alemanha completamente sem defesa", afirmou Rocha Lima (11.10.1914 [20.08.1914]).

Segundo Olivier Compagnon: "num momento em que a figura do jornalista não existe ainda de maneira autônoma e muitas vezes se confunde com as do político, do diplomata ou do escritor polígrafo, a imprensa é o primeiro revelador dessa inflexão que se representa entre as elites ao mesmo tempo que constitui uma prova para setores mais amplos da população" (2014, p.68).

Não é claro como Rocha Lima obteve sua participação como articulista no Jornal do Commercio. Ele sugere que escreveu atendendo a pedido “do maior jornal brasileiro" (Rocha Lima, 11.10.1914 [20.08.1914]). Inicialmente o Jornal do Commercio optou por seguir a postura da diplomacia brasileira de manter a neutralidade. Divulgou alguns escritos pró-Alemanha, como os de Rocha Lima, ao lado de textos favoráveis ao lado oposto. Mais adiante, esse esforço de aparente neutralidade daria lugar a uma posição francamente pró-Aliada. Enquanto no Rio de Janeiro

2 PAAA (Politisches Archiv des Auswärtigen Amtes) - Pasta 121944 - Kaiserlich Deutsches Konsulat Porto Alegre am 23 abr. 1915. O Arquivo Político do Ministério das Relações Exteriores da Alemanha encontra-se em Berlim e abriga a documentação referente à política externa alemã desde a fundação da Confederação da Alemanha do Norte, em 1867. Os documentos referentes ao Brasil à época da Primeira Guerra registram o empenho do cônsul alemão em Porto Alegre em relatar o estado da arte da imprensa e da população em relação ao conflito, principalmente no tocante à Alemanha e aos teuto-brasileiro. 
jornais como o Correio da Manhã ou Jornal do Brasil abriram espaço para a divulgação de opiniões pró-Alemanha, a maior parte deles, como A Noite, Gazeta de Notícias e O Imparcial "inundam a capital brasileira com sua aliadofilia” (Compagnon, 2014, p.71). Compagnon alinha o Jornal do Commercio a esta imprensa aliadófila, mas a publicação de uma coluna como a de Rocha Lima sugere que o periódico, ao menos no início, esteve mais próximo do primeiro grupo. Sidney Garambone afirma que alguns anos antes da Guerra o periódico apresentara "uma certa atração pelo nascente império alemão" (2003, p.51). Mais tarde, a crescente postura pró-Aliada mobilizou a imprensa e o circuito diplomático alemães. Em 5 de maio de 1915, o jornal alemão Berliner Börsen Curier queixou-se do favoritismo do Jornal do Commercio pelos Aliados. "Essa postura do jornal é tanto incompreensível quanto mais enigmática, uma vez que grande número de seus leitores, sobretudo dos círculos culturalmente mais elevados da sociedade brasileira, conhecem muito bem a Alemanha e não têm uma disposição anti-germânica". ${ }^{3} \mathrm{O}$ enigma tornava-se menos misterioso mediante a informação de que o Jornal do Commercio devia avultada quantia à agência francesa Havas.

A representação diplomática alemã atribuiu a inclinação aliadófila do Jornal do Commercio ao seu proprietário e redator-chefe Carlos Rodrigues, que passara cinco anos em Londres onde atuou como colaborador de jornais ingleses e correspondente do matutino brasileiro. Para ele, a Alemanha seria "terra incógnita", a qual enxergava não pelas lentes francesas, como a maioria, mas inglesas. Em maio de 1915, a representação alemã do Rio comunicou a Berlim que Rodrigues estava para deixar a direção do Jornal do Commercio depois de 25 anos. Sugeriu manobras para adquirir parte do capital da empresa, a fim de ampliar a influência germânica naquele que era então o mais importante periódico da capital. ${ }^{4}$

O fato de se encontrar na Alemanha, no epicentro do cataclismo inicialmente europeu, legitimou o discurso de Rocha Lima. O título de sua

3 PAAA - Pasta 121944 "Die Albernen Kugeln und die deutsch-feindliche Auslandspresse", Berliner Börsen Curier (recorte).

4 PAAA - Pasta R121944 Kaiserlich Deutsche Gesandtschaft in Brasilien, 03 maio 1915. 
coluna é "Da Alemanha", o que denota que ele descreve o andamento da guerra e pronuncia suas opiniões como testemunha próxima dos eventos, à semelhança de um repórter correspondente de guerra. Ele chegou a estar no campo de prisioneiros russos em Cottbus, próximo a Berlim, onde foram detidos os derrotados pelo marechal Hindenburg na famosa batalha de Tannenberg. Ali investigou epidemia de tifo exantemático. A doença, estreitamente vinculada a conflitos militares e que teria grande incidência na Grande Guerra foi seu objeto de estudo naqueles anos, levando-o à identificação do agente causador (Silva, 2011).

O médico brasileiro reforçou esta proximidade com o cenário do conflito. Em texto sobre um ano da Guerra, atestou que suas informações eram originárias de fontes seguras - amigos, colegas e conhecidos que haviam estado no front. Aludiu ao fato acima mencionado de ele próprio ter passado seis meses num campo de prisioneiros russos e de ter assistido e tratado, no Instituto de Hamburgo, indivíduos feridos nas batalhas. Colocou-se como autêntico conhecedor do modo de pensar alemão, diferenciando-se dos demais que possuíam apenas uma ideia superficial do país:

Conhecer a Alemanha não é porém ter aqui permanecido por tempo mais ou menos longo a palestrar nos consulados, a ler o Figaro e o Matin nos cafés, frequentando um curso qualquer ou o demi-monde, assistindo a paradas militares, suportando por esnobismo uma ou outra ópera de Wagner, trocando banalidades em visitas de cerimônias, tomando a opinião do barbeiro pelo pensamento alemão, orientando-se bem não só nas avenidas em que se flana como mesmo em muitas ruelas obscuras mas sem nunca encontrar o caminho das bibliotecas, e ter finalmente daqui saído dirigindo mal e com dificuldade a língua alemã, completamente estranho portanto ao movimento político e intelectual do país e levando ainda muitos senão todos os preconceitos trazidos, filhos da nossa educação exclusivamente francesa (Rocha Lima, s.d.). ${ }^{5}$

5 ROCHA LIMA, Henrique da. Um ano de guerra na Allemanha. Texto Datilografado, s.d.. Arquivo Rocha Lima, Centro de Memória do Instituto Biológico de São Paulo. 
Para Rocha Lima, a Guerra era produto da inquietação e inveja causada pelo célere e, segundo ele, pacífico desenvolvimento industrial da Alemanha. Não haveria motivos para que esse povo se lançasse a uma guerra na qual seriam sacrificados, e da qual não esperavam vantagem alguma capaz de compensar os prejuízos. Ainda mais por tratar-se de um povo que costumava friamente "pesar os prós e os contras" (Rocha Lima, 11.10.1914 [20.08.1914]):

É lógico supor que seja a Alemanha que tenha interesse em lançar mão de meios violentos para destruir adversários que não conseguiram impedir o seu engrandecimento pacífico? É lícito acreditar que um povo cuja riqueza e bem estar constantemente cresce e que em caso de guerra não dispõe como a Inglaterra de tropas mercenárias mas tem que, sem diferença de posição social, expor a própria vida, tenha desejo de sacrificar tudo em uma guerra difícil contra inimigos muito mais numerosos? Parece evidente que não (Rocha Lima, 11.10.1914 [20.08.1914]).

A única ambição que os alemães poderiam ter, de conquistas coloniais, eles saberiam ser bloqueada pela Inglaterra, detentora de força naval superior. A acusação de pretensões de hegemonia pela Alemanha teria sido a base de toda a campanha contra ela e o cerne da política europeia nos últimos anos (Rocha Lima, 11.10.1914 [20.08.1914]). Conforme Rocha Lima, o governo alemão havia se lançado num "empenho sincero" de evitar a guerra a todo o custo, enquanto que os alemães teriam esperança de que a diplomacia encontraria um meio de evitá-la. Por isso considerava um contrassenso afirmar que a Alemanha era a causadora da guerra. A Inglaterra seria a mais aplicada em destruir, pela força, o que não havia conseguido em tempos de paz. Os franceses haviam se atirado à guerra alimentados pelo espírito revanchista, enquanto que os russos miravam dominar os eslavos da Áustria e os Bálcãs a fim de conquistar Dardanelos. "A estrada comum que conduz ao fim almejado passa por Berlim”, escreveu o médico brasileiro (Rocha Lima, 11.10.1914 [20.08.1914]). 
A tentativa de livrar a Alemanha da responsabilidade pela guerra tal como ensaiou aqui Rocha Lima, ganhou o espaço público do país depois que o Tratado de Paz ratificou que o Império de Guilherme II fora o causador do conflito. O debate em torno da chamada Kriegsschuldfrage - a questão da culpa da guerra - rebateu na historiografia alemã e internacional, originando densa literatura sobre o tema, dividida grosso modo entre abordagens estruturalista-funcionalistas e intencionalistas. ${ }^{6}$ As visões sobre a responsabilidade pelo cataclismo modificaram-se tão logo as armas silenciaram, modificando-se ao sabor das tendências historiográficas e do contexto político internacional (Keiger, 2010, p.20).

Desde então, a discussão sobre as causas da Guerra ocupou os historiadores de forma "quase obsessiva" (Mombauer, 2002, p.1). A centralidade da Alemanha nesse debate - de certa forma percebido pelos contemporâneos, como registra Rocha Lima - deveu-se à cláusula de culpa de Guerra incluída no Tratado de Paz, à responsabilidade imputada pelos seus inimigos ainda durante o conflito e pelo maior peso atribuído pelos próprios historiadores às decisões das lideranças alemãs (Mombauer, 2002).

A tese da Alemanha como causadora da Guerra ganhou novo alento com os trabalhos do alemão Fritz Fischer, que na década de 1960 argumentou que de fato seu país havia sido o principal responsável pelo conflito, para o qual se preparava desde pelo menos 1912. A "tese de Fischer" foi refutada, revista e complexificada pela historiografia mais recente, mas ainda assim o papel da Alemanha na deflagração da Guerra continua controverso. Nas análises sobre a "crise de Julho" - o contexto imediato que levou à Guerra - permanece não-respondida a extensão em que o apoio do Reich à Áustria-Hungria desencadeou reações que extrapolaram os Bálcãs e em que medida a Alemanha poderia ter controlado a beligerância dos Habsburgos (Jones, 2013). Segundo Heather Jones (2013), a historiografia recente mostra que esse suporte foi bastante

6 Visão geral sobre a historiografia da Primeira Guerra pode ser obtida em MOMBAUER, 2002 e WINTER, PROST, 2005. 
claro e que os líderes alemães estavam bem conscientes de que o apoio para os austro-húngaros enfrentarem a Sérvia trazia o risco de o conflito extravasar para todo o continente. Permanece em litígio se e em que extensão os alemães ativamente queriam essa escalada a fim de reagir contra o que acreditavam ser um cerco formado pelos países vizinhos ou se apostaram que a "carta branca" aos seus aliados não acarretaria um confronto para além dos Bálcãs. "Embora algumas das visões de Fischer permaneçam controversas, poucos historiadores contestam o fato de que a Alemanha estava mais disposta que qualquer outra potencia a arriscar-se à Guerra em 1914", concluem Matthew Seligmann e Roderick McLean (2000, p.140).

No plano militar, autores como Annika Mombauer (2002) afirmam que os militares alemães foram motivados para a Guerra por uma combinação de disposição à belicosidade e consciência do relativo declínio militar em que se achava o império de Guilherme II em relação aos seus rivais europeus. Uma ofensiva militar rápida seria a única alternativa reconhecida por eles, frente à vulnerabilidade do território do Reich e à inconveniência de um conflito mais longo. Talvez dali a alguns anos o exército alemão não tivesse condições de deflagrar esse ataque "preventivo". Para Mark Hewitson (2004), os alemães apostaram na Guerra movidos pela convicção de que podiam vencê-la.

Visão mais abrangente e atenta às correntes que vêm complexificando os estudos sobre a Primeira Guerra é fornecida por Christopher Clark (2014). Para Clark (2014) não faz sentido atribuir responsabilidades a nações, indivíduos ou grupos pela irrupção da Guerra. Para ele, esta resultou de um processo complexo de decisões em cadeia tomadas antes e depois de julho de 1914, as quais sinergicamente contribuíram para aquele resultado de consequências imprevistas. As decisões são analisadas por múltiplas camadas de determinações, que abrangem as motivações dos agentes, as posturas das elites mediante a Guerra, as mentalidades políticas e a atitude da opinião pública (Mombauer, 2002; Winter, Prost, 2005; Jones, 2013). Segundo Heather Jones (2013), este olhar deve-se às contribuições da história cultural, que também auxiliou na reavaliação da disputa por hegemonia bélica naval entre Inglaterra e 
Alemanha, mencionada por Rocha Lima em seu texto. Jan Rüger (2007) analisa a construção dessa disputa em termos de um "teatro naval" cujos rituais - lançamento de navios de guerra, revisão da frota - trouxeram a marinha ao cenário público, conferiram valor simbólico aos seus oficiais e ganharam o público por meio de performances protagonizadas pelos líderes políticos e militares.

Se por um lado Fischer enfatizou a responsabilidade da Alemanha pela Guerra, por outro apontou-se o papel da Inglaterra em conferir-lhe abrangência europeia e em desencadear a corrida armamentista naval. $\mathrm{O}$ desafio que a Alemanha começou a representar para os ingleses, ciosos da superioridade de sua esquadra, fez com que eles passassem a encará-la como principal oponente e a forjar, na opinião pública britânica, a ideia de uma possível guerra (Krumeich, 2010, p.12).

Para Rocha Lima coubera à Rússia evitar a precipitação do conflito, cessando "o apoio voluntário e premeditado à Sérvia”, já que a Alemanha não poderia em hipótese alguma abandonar a aliança com a Áustria: "A mobilização do exército russo contra a Áustria bastaria para tornar inevitável a intervenção da Alemanha" (Rocha Lima, 11.10.1914 [20.08.1914]). Por essa razão, a Rússia seria "a única culpada desta catástrofe horrenda”, enquanto a Inglaterra aproveitava a ocasião "para destruir uma rival poderosa" (Rocha Lima, 11.10.1914 [20.08.1914]). À medida em que sucederam as lutas, Rocha Lima modificou sua opinião: a Inglaterra, que segundo ele apenas esperava um pretexto para declarar Guerra à Alemanha, "cada vez mais aparece como o verdadeiro encenador desta tragédia horrível", escreveu em setembro de 1914 (Rocha Lima, 25.10.1914 [12.09.1914]). ${ }^{7}$ A Alemanha teria sido vítima dessa correlação de forças, pegando em armas apenas "para proteger a própria existência" e defender-se "contra adversários que, invejosos de seu progresso, de seu bem estar e de seu engrandecimento, procuram destruir pela força o que não conseguiram sobrepujar em concorrência pacífica” (Rocha Lima, 11.10.1914 [20.08.1914]). A ideia de um país

7 ROCHA LIMA, Henrique da. Da Allemanha - Hamburgo. Jornal do Commercio (Rio de Janeiro), p.3, 25 out. 1914. 
sitiado por vizinhos invejosos e beligerantes, obrigado a se defender, foi bastante explorada pela propaganda alemã. Abastecia-se da convicção alimentada pelo nacionalismo e pelo darwinismo social segundo os quais a disputa das nações por poder era a base da política mundial. Tal ideário atravessou fronteiras de classe e impregnou todo o espectro político (Ther, 2014; Krumeich, 2010, p.10).

O médico brasileiro compartilhou com segmentos da sociedade alemã uma visão bastante negativa dos russos e eslavos em geral. Os estereótipos negativos e racistas foram, entretanto, mais utilizados pela propaganda feita por agentes privados do que pela oficial (Ther, 2014). Ecoando esta "russofobia", Rocha Lima julgou a aliança entre França e Rússia "sentimental e funesta", pois a primeira teria sacrificado nela seus ideais civilizatórios ao juntar-se a um país "inculto e politicamente atrasadíssimo, mas com um grande exército". O desejo de vingança dos franceses faria com que suas conquistas civilizatórias fossem "esmagadas a patas de cavalos pelos cossacos analfabetos". "Para os alemães é doloroso ver a civilização francesa ao serviço de um povo bárbaro", registrou no texto de 07 de setembro de 1914, pesar que seria menor que o ódio aos vizinhos do oeste (Rocha Lima, 18.10.1914 [07.09.1914]). ${ }^{8}$ Dessa forma, Rocha Lima denunciava uma contradição da propaganda Aliada, que retratava a Guerra como uma luta da civilização e da liberdade contra a barbárie e o autoritarismo, mas incluía em sua aliança a Rússia czarista, autocrática e atrasada. Julgava uma ironia os aliados esperarem "a realização dos ideais de democracia e civilização que todos os homens cultos e de boa fé deles esperam" através das conquistas do "colosso russo" (Rocha Lima, 06.12.1914). ${ }^{9}$

Um dos principais alvos de Rocha Lima foi a propaganda da França e da Inglaterra, que segundo ele deturpava a verdade e propalava falsas

8 ROCHA LIMA, Henrique da. Da Allemanha - Hamburgo. Jornal do Commercio (Rio de Janeiro), p.4, 18 out. 1914.

9 Neste caso, 06 dez. 1914 corresponde à data de assinatura do texto, consultado na versão datilografada depositada no acervo pessoal de Rocha Lima e não de publicação, a qual não foi possível ser recuperada já que à época da pesquisa o microfilme referente a janeiro de 1915, provável período em que o artigo veio a lume, estava danificado. 
derrotas do exército alemão, chegando mesmo a atribuir a este planos inverídicos. Segundo ele, na Alemanha as notícias divulgadas pelos aliados chegavam a causar risos, quando não indignação pelas calúnias. A campanha de mentiras seria mera continuação daquilo que a França já fazia antes mesmo da Guerra: o ódio contra a Alemanha "cultivado artificialmente” (Rocha Lima, 18.10.1914 [07.09.1914]). Mas para o pesquisador brasileiro a Inglaterra saía à frente na falsificação da verdade. Importantes jornais ingleses estariam deliberadamente divulgando versões falsas de comunicados alemães e fraudando fotografias (Rocha Lima, 10.11.1914 [05.10.1914]). "A mentira constitui a arma mais forte dos inimigos da Alemanha", escreveu nosso autor (Rocha Lima, 01.11.1914 [18.09.1914])..$^{10}$

Em sua opinião, o Brasil oferecia campo fértil para tais informações enviesadas por desconhecer a civilização alemã, devido à falta de contato com seu povo e pela dificuldade representada pela língua. Em contrapartida, haveria uma identificação com a Inglaterra e França, em suas palavras "senhores do telégrafo", dedicados a "amordaçar a verdade": "Os Aliados, com o domínio do telégrafo conseguem o domínio intelectual do mundo" (Rocha Lima, 18.10.1914 [07.09.1914]). Referia-se, aqui, à já mencionada predominância de Havas e Reuters como fontes de notícias internacionais, principalmente nos países neutros.

Rocha Lima imputou à propaganda Aliada o objetivo de "impressionar os povos vassalos semi-selvagens ou excitar as classes mais baixas do próprio país" (Rocha Lima, 06.12.1914). "Censure-se, condene-se e combata-se uma tal política, mas não se repitam imputações caluniosas dos agitadores da plebe intelectual do mundo", aconselhou aos leitores, incentivando interpretações independentes das privilegiadas pelos franceses. Ele denunciou a tendência de escolherem o Brasil como "objeto de demonstração da influência dos Aliados sobre a América do Sul”, uma posição muito desabonadora para seu país, assim reduzido à servidão intelectual. "O meu desejo é unicamente que a campanha anti-alemã,

10 ROCHA LIMA, Henrique da. Da Allemanha - Hamburgo. Jornal do Commercio (Rio de Janeiro), 01 nov. 1914. 
se vitoriosa, tenha ao menos um nível elevado e digno de nossa pátria”, asseverou. Em países de mesmo nível cultural da Alemanha, como Holanda, Dinamarca, Suécia e Noruega as "calúnias absurdas com que se procura tornar odioso o exército alemão não encontram eco", afirmou (Rocha Lima, 01.11.1914 [18.09.1914]).

Para Rocha Lima, o eco da propaganda Aliada no Brasil devia-se à "vassalagem intelectual" das classes eruditas em relação à cultura francesa. "A atmosfera intelectual do nosso país é, incontestavelmente, um produto da literatura francesa (...) A nossa literatura e nossa imprensa refletem constantemente ideias francesas", escreveu em 06 de dezembro de 1914. Dessa forma ele reconhecia a sobreposição da aliadofilia com a francofilia (Compagnon, 2014, p.82). Esse predomínio acarretava uma visão equivocada dos alemães: "fazemos deles uma ideia completamente falsa que nos é inspirada por um inimigo rancoroso, humilhado em uma guerra infeliz e sobrepujado na importância mundial" (Rocha Lima 06.12.1914). O pequeno número dos que conheciam o idioma e a mentalidade alemães eram os únicos capazes de quebrar "as cadeias que desde a mais tenra infância nos vão subordinando ao pensamento francês" (Rocha Lima, s.d.). Sua própria formação intelectual confirmaria essa hegemonia: "aos 10 anos já decorava poesias francesas, aos 12 ouvia e cantava emocionado a Marselhesa (...) e quando aos 21 partiu para a Alemanha trazia latentes todos os preconceitos filhos da influência francesa" (Rocha Lima, 06.12.1914). Dentre esses preconceitos e ideias vagas em relação à Alemanha enumerou o absolutismo, militarismo, menosprezo do direito e culto da força bruta. No entanto, contrariamente à maioria dos brasileiros, passara a conhecer com profundidade a mentalidade alemã, "devido a uma longa permanência neste país, à qualidade de suas relações e à natureza de sua profissão", justificou mais tarde (Rocha Lima, s.d.).

Como conhecedor da cultura alemã, cabia-lhe neutralizar esse "partidarismo descomedido", que levava "a se referir a um dos povos mais cultos do mundo em termos grotescamente injuriosos como bárbaros, vândalos, hunos, etc" (Rocha Lima, 06.12.1914). Sua missão seria destinada "aos patrícios que se interessam pela verdade", possibilitando-os 
formar um juízo independente das notícias divulgadas pelos adversários da Alemanha (Rocha Lima, 06.12.1914). Além de apresentar os alemães como um povo pacífico em todo seu desenvolvimento, caracterizou como "acusações absurdas" as de que o Kaiser e sua camarilha militar teriam provocado a Guerra à revelia da população (Rocha Lima, 11.10.1914 [20.08.1914]). "Há maior contrassenso do que atribuir esta guerra a um partido militar alemão quando se vê o apoio absoluto e unânime do povo inteiro (inclusive dos oposicionistas e antimilitaristas os mais extremados) à atitude do governo no momento político que deu lugar à guerra?", arguiu (Rocha Lima, 06.12.1914). O que se via era um povo unido e confiante no seu governo e exército, mesmo sem saber quem estava na condução dos planos militares e quais eram estes, mesmo porque seriam mantidos sob "o silêncio mais absoluto" (Rocha Lima, 25.10.1914 [12.09.1914]). O exército alemão era "uma organização colossal sem heróis populares" (Rocha Lima, 18.10.1914 [27.08.1914]). Tal confiança era fruto do "elevadíssimo nível moral da oficialidade do exército alemão". Evidências disso eram a aprovação unânime pelo parlamento alemão de crédito de 3 milhões de marcos para a guerra e a apresentação espontânea de um milhão e meio de voluntários durante a mobilização (Rocha Lima, 11.10.1914 [20.08.1914]). As diferenças políticas, representadas pelas organizações partidárias, haviam dado lugar à união conferida pelo dever com a pátria (Rocha Lima, 18.10.1914 [07.09.1914]). Para Rocha Lima, a confiança entre o governo e o povo alemão dava-se principalmente em momentos de incerteza, como na terceira semana de setembro de 1914, quando, após uma sucessão de vitórias, a situação das tropas na França tornara-se indeterminada: "É em um momento destes, cheio de apreensões e incertezas que se pode apreciar a confiança recíproca que une o povo ao governo. O governo confia na energia de caráter do povo, pondo à prova a paciência confiante com que este, embora sequioso de notícias, se resigna e espera" (Rocha Lima, 01.11.1914 [18.09.1914]).

O médico brasileiro narrou o entusiasmo com que os cidadãos rumaram para o front - "um espetáculo imponente e grandioso", avaliou. Aproveitou para enaltecer a ordem e pontualidade dos alemães, que 
além disso teria como uma das qualidades mais admiráveis "o sentimento do dever capaz de dominar o egoísmo" (Rocha Lima, 18.10.1914 [27.08.1914]). Todas as classes sociais indistintamente foram convocadas para cumprir seu dever com a pátria: “Todos, desde o camponês boçal até o mais completo intelectual, desde o simples operário até o aristocrata feudal partem com a mesma satisfação e orgulho, com o mesmo entusiasmo e sobretudo com a mesma confiança" (Rocha Lima, 18.10.1914 [27.08.1914]).

Rocha Lima contrastou a discrição, serenidade e precisão dos informes oficiais alemães com a forma como os Aliados trombeteavam suas vitórias. Enquanto o general Joffre anunciava a plenos pulmões a expulsão das tropas alemãs do território francês, "calam-se tanto as autoridades como os críticos militares alemães que não possuem a habilidade de descrever as vitórias antecipadamente, mas limitam-se tão somente a comentar fatos consumados" (Rocha Lima, 25.10.1914 [12.09.1914]). ${ }^{11}$ As críticas nesse sentido também foram endereçadas aos aliados da Alemanha, os austríacos, que à semelhança dos franceses e ingleses, divulgavam notas oficiais "destinadas a causar ao leitor uma impressão diferente da que a verdade causaria". "Sucessos parciais sem importância decisiva, atos de bravura admiráveis, enfraquecimento do inimigo, medidas estratégicas prometedoras em andamento, tudo isso é disposto e relatado de modo a encobrir a situação precária real", admoestou o brasileiro (Rocha Lima, 01.11.1914 [18.09.1914]).

Diferentemente dos aliados, os alemães também evitariam insultos e escárnios contra os inimigos:

11 "Bem conhecido é esse hábito dos franceses de anunciarem com grande antecedência os grandes feitos de que se julgam capazes. Se isso em tempo de paz já não conseguia impressionar senão os leitores ingênuos de certos jornais parisienses, agora depois que os previamente tão celebrados oiseaux de France não conseguiram realizar uma só das grandes façanhas anunciadas, depois que os russos que iam esmagar os alemães a patas de cavalos foram afogados nos lagos masúricos e a arqui-celebrada esquadra inglesa julga mais prudente não tentar destruir a esquadra alemã as habituais ameaças dos franceses não conseguem provocar aqui senão um riso complacente" escreveu ROCHA LIMA em 05 out. 1914. 
Enquanto aqui nem mesmo depois da Batalha de Tannenberg em que os russos sofreram uma derrota tremenda e completa alguém se lembrou de qualificar os generais e soldados russos de incapazes e ineptos ou de procurar lançar sobre eles o ridículo, lê-se a todo instante na imprensa inimiga e na dos países por ela influenciados que os generais alemães erram ou se enganam ou são surpreendidos por manobras geniais dos adversários (Rocha Lima, 06.12.1914).

Conforme o cientista, os alemães recebiam as vitórias de suas tropas com orgulho, mas também moderação, lembrados pelo governo "de que se está ainda em começo de uma campanha longa e difícil" (Rocha Lima, 25.10.1914 [12.09.1914]). A notícia de que as tropas russas esmagariam a Alemanha não corresponderia à realidade. Apesar do grande contingente de oficiais e do bom armamento, o exército do czar avançava pouco, argumentou (Rocha Lima, 06.12.1914). Também não seria verdade que o exército alemão na França encontrava-se em estado de fadiga ou no final de suas reservas (Rocha Lima, 25.10.1914 [12.09.1914]). Esclareceu que o número de voluntários perfazia milhões. O médico brasileiro por diversas vezes enfatizou a inferioridade numérica do exército alemão e a desproporção de forças frente aos Aliados (Rocha Lima, 11.10.1914 [20.08.1914], 01.11.1914 [18.09.1914]). ${ }^{12}$ Destacou particularmente a disparidade entre as forças russas e austro-húngara, o que tornava heroica "a bravura insuperável com que todas as raças (inclusive eslavos e latinos) desta nação heterogênea se tem batido, a resignação estoica com que suportaram o choque tremendo do colosso moscovita" (Rocha Lima, 06.12.1914). Achava um despropósito retratar a Áustria como um subjugado pelas tropas russas, enquanto que a França, em situação pior, era caracterizada como vencedora dos alemães (Rocha Lima, 06.12.1914). Denunciou o emprego de tropas coloniais

12 "Contra dois países com apenas um total de 118.000.000 de almas combatem hoje seis nações representando um total de 230.000.000 de habitantes e talvez amanhã outras mais. Não há quem ignora, principalmente nos países influenciados pela literatura francesa, que segundo os dados oficiais o exército franco-russo por si só é numericamente superior ao da tríplice aliança" (ROCHA LIMA, 11.10.1914 [20.08.1914]). 
pelos ingleses e franceses, mais uma evidência aos países neutros de que a luta contra a Alemanha não era travada em favor da liberdade, do progresso e da civilização, "como se afirma hipocritamente", mas servia "à satisfação de ódios e ambições dos que não podem sobrepujar a Alemanha em concorrência pacífica" (Rocha Lima, 01.11.1914 [18.09.1914]). Nesse sentido, Rocha Lima estava afinado com o discurso dos intelectuais alemães para quem a utilização de negros e eslavos no teatro de guerra europeu pelos aliados representava o cume da barbárie e uma contradição à ideia de que estes representavam os fiadores da civilização ocidental cristã (Prochasson, 2010, p.326).

"Não é assombrosa a energia e bravura com que este povo se bate quase contra o mundo inteiro?" admirou Rocha Lima. Ele via como prova da superioridade do exército alemão o fato de as batalhas ocorrerem fora do território do Reich, mesmo tendo de dividir-se entre os fronts ocidental e oriental (Rocha Lima, 06.12.1914). Os aliados, por sua vez, compensariam as perdas militares com anúncios fantasiosos divulgados pela propaganda: "Até agora, em todos os combates em que os aliados não vencem anunciam que os alemães foram dizimados e todas as vezes que cedem terreno é porque os alemães aparecem em número muito superior" (Rocha Lima, 25.10.1914 [12.09.1914]). A esquadra alemã monitorava as costas da Alemanha a fim de garantir a navegação pelo Mar Báltico e do Norte, lembrou Rocha Lima (10.11.1914 [05.10.1914]). Outro teatro de luta era a baía de Kiauchau, onde tropas inglesas, auxiliadas por japonesas, tentavam pôr fim ao domínio germânico naquele território: ${ }^{13}$

13 Os alemães obtiveram a concessão do território da baía de Kiauchau em 1898, depois de terem ocupado a região com tropas. O interesse dos alemães por uma possessão naquele ponto tinha a ver com os objetivos de hegemonia naval e com a necessidade de resguardar rotas comerciais estratégicas. Kiauchau ficou sob domínio alemão na condição de protetorado, prevista para durar 99 anos, à semelhança do acordo entre ingleses e chineses na concessão do território de Hong Kong. Durante a Primeira Guerra, os chineses revogaram a concessão alemã e o território foi ocupado pelos japoneses, retornando ao controle da China em 1922. A esse respeito ver HEROLD, 2006. 
Creio que é um fato único na história que um país se veja obrigado a dividir por tal forma as suas forças a fim de se defender de tantos inimigos que o atacam por todos os lados. Mais admirável ainda aparece a força defensiva da Alemanha quando se compara as dimensões dela e suas colônias com a dos inimigos e respectivas colônias. A desproporção é monstruosa! E no entanto o solo alemão só é pisado atualmente por prisioneiros inimigos. O mesmo não podem dizer os seus vizinhos inimigos apesar de auxiliados pelo mundo inteiro (Rocha Lima, 10.11.1914 [05.10.1914]).

Mas era no front oriental, onde enfrentava a Rússia, que para Rocha Lima os alemães travavam sua campanha "mais difícil, mais penosa e mais gloriosa" (Rocha Lima, 06.12.1914). As dificuldades do território russo - estradas intransitáveis, dificuldades de comunicação, pragas de piolhos -abrilhantariam as vitórias das tropas alemãs (Rocha Lima, 06.12.1914).

O pesquisador brasileiro procurou dimensionar aos seus leitores o impacto da Guerra no cotidiano dos alemães. Em termos econômicos, sublinhou que grande parte da indústria encontrava-se paralisada, ao passo que outra parte era tomada de intenso dinamismo. No segundo caso, destacou a indústria de bandeiras, sintoma do espírito nacionalista que tomou de assalto a população, e a de armamentos. Narrou com entusiasmo as inovações bélicas e seu poder destrutivo, capaz de fragilizar as mais potentes fortalezas erigidas pelos inimigos da Alemanha (Rocha Lima, 25.10.1914 [12.09.1914]).

Aspecto particularmente problemático que Rocha Lima teve de enfrentar em seus textos foi o das barbáries cometidas pelas tropas do Kaiser no território belga. A invasão da Bélgica pela Alemanha foi um momento dramático no "front intelectual" e na arena pública. O ataque de Dinant, o incêndio da biblioteca universitária de Louvain, destruições de vilas inteiras e atentados contra as populações civis intensificaram as investidas na imprensa contra os alemães. Segundo John Horne e Alan Kramer (2004), logo nos primeiros dias de invasão da Bélgica os militares alemães praticaram execuções contra civis, inclusive de 
mulheres e crianças. Fizeram reféns, assassinaram homens na frente de suas mulheres e filhos, usaram civis como escudos humanos na invasão de outras localidades e queimaram igrejas e residências. Os autores afirmam que as cruéis atrocidades cometidas pelos alemães deveram-se ao rancor despertado pela resistência dos belgas com a qual não contavam e que julgavam ilegítima.

Os relatos reforçaram a noção de um exército bárbaro, síndrome de uma cultura autocrática e militarista, inimiga dos valores da civilização. Nesse momento "elabora-se de fato a imagem de uma Bélgica martirizada, que seria a alegoria da neutralidade escarnecida" (Compagnon, 2014, p.61). Havia a ideia de que ao lado de uma Alemanha autoritária, imperialista e beligerante, existia uma outra, culta e célebre pelas realizações no terreno artístico e científico. Esta representação ficou comprometida, quando em outubro de 1914 os mais reputados representantes do mundo acadêmico germânico assinaram um manifesto traduzido para mais de dez línguas e publicado nos principais jornais alemães. Na carta intitulada "An die Kulturwelt" (ao mundo cultural), cientistas da envergadura de Max Planck, Ernst Haeckel, Fritz Haber, Wilhelm Roentgen, Wilhelm Ostwald, Walter Nernst, Albert Neisser, Paul Ehrlich, August von Wassermann, entre outros, combateram a ideia de que a Alemanha havia causado a guerra e de que ferira criminosamente a neutralidade belga. Repudiaram as acusações de crimes das tropas alemãs na Bélgica e defenderam a identidade entre a cultura e o militarismo germânicos. ${ }^{14}$ O clamor público provocado pela invasão da Bélgica em várias partes do mundo levou a Alemanha a coordenar sua propaganda oficial, cujo discurso retroagiu a uma postura defensiva (Welch, 2000, p.24).

Em sintonia com os expoentes da ciência alemã, Rocha Lima questionou a neutralidade belga, de modo a justificar sua invasão pelo exército germânico. Segundo ele, documentos encontrados na chancelaria e nos

14 Sobre o chamado "Manifesto dos 93" e seu impacto nas relações científicas internacionais ver SCHROEDER-GUDEHUS, 1973. STERN, 2004, também aborda o tema num dos capítulos sobre o mundo acadêmico alemão antes e durante o período da Primeira Guerra. A relação do Manifesto dos 93 com a propaganda de guerra encontra-se em UNGER-STERNBERG, UNGER-STERNBERG, 1996. 
órgãos oficiais da Bélgica indicavam que o país já tencionava entrar em guerra contra a Alemanha, inclusive com o apoio de tropas francesas. Nesse sentido não era neutro, "mas sim um aliado secreto da França" (Rocha Lima, 01.11.1914 [18.09.1914]). Seria mais um sinal de que os aliados preparavam-se para a Guerra muito antes da Alemanha, esta ainda crente na possibilidade de manter a paz (Rocha Lima, 01.11.1914 [18.09.1914]). A invasão da Bélgica teria sido motivada pela necessidade de se proteger, cabendo ao soberano deste país simplesmente renderse para cessar as hostilidades, à semelhança da atitude do governo de Luxemburgo: "O futuro virá a mostrar se foi o governo belga com esta atitude ou o do Luxemburgo protestando mas se submetendo que melhor defendeu os interesses do seu povo". Apesar de a resistência belga ser “admirável e gloriosa”, na prática significava enorme desvantagem para seu povo (Rocha Lima, 25.10.1914 [12.09.1914]).

Na visão de Rocha Lima, as ações dos alemães na Bélgica, como o arrasamento de cidades inteiras tinham o objetivo de neutralizar os franco-atiradores. "A não ser em caso de represália provocado pelos franco atiradores os alemães são os indivíduos os mais pacatos que se pode imaginar", justificou (Rocha Lima, 01.11.1914 [18.09.1914]). A destruição da Catedral de Reims e da biblioteca de Louvain justificavam-se como respostas do exército alemão aos ataques das tropas adversárias (Rocha Lima, 18.10.1914 [07.09.1914], 01.11.1914 [18.09.1914], 06.12.1914). Enquanto isso, silenciava-se sobre as atrocidades belgas, francesas e inglesas. Como exemplos, o pesquisador brasileiro citou as brutalidades perpetradas pelos franceses na invasão da Lorena e o fato de utilizarem, junto com os ingleses, as chamadas balas dundum, projéteis de ponta oca que causam grandes ferimentos quando atingem o organismo e que por isso haviam sido proibidas pelas convenções internacionais (Rocha Lima, 18.10.1914 [07.09.1914], 01.11.1914 [18.09.1914]). Invertendo o discurso, apresentou os alemães como vítimas da população belga, como no caso de soldados atacados por mulheres e crianças com armas improváveis como agulhas de crochê (Rocha Lima, 10.11.1914 [05.10.1914]). Além disso, ingleses e franceses atacavam cidades alemãs não fortificadas (Rocha Lima, 06.12.1914). 
Foi em torno dessas barbáries que Rocha Lima protagonizou controvérsia pública com o professor da Faculdade de Medicina do Rio de Janeiro, Bruno Álvares da Silva Lobo. Lobo foi um dos componentes da missão médico-militar que o Brasil enviou à França para participar da assistência às tropas aliadas. ${ }^{15}$ De Paris, ele escreveu em 29 de janeiro de 1915 carta divulgada pela imprensa brasileira com o título "A todas as senhoras brasileiras, sobretudo às que têm filhos" ${ }^{16}$ Foi publicada por O Imparcial e repercutida por outros veículos, como A Tribuna. Dirigiu-se diretamente a Rocha Lima, aludindo ao manifesto dos intelectuais alemães:

Os cientistas alemães dirigiram aos intelectuais dos países neutros uma exposição justificativa do proceder do governo alemão e de seus exércitos. O meu ilustre colega Rocha Lima, em artigos sucessivos no Jornal do Commercio, do Rio de Janeiro, procurou também atenuar as violências e barbaridades cometidas pelos soldados e oficiais do Kaiser. Nestas condições, conhecendo eu o espírito reto de Rocha Lima, certamente iludido, ouso abordar uma das infâmias praticadas pelos alemães, pedindo a sua opinião e ao mesmo tempo o obséquio de tornar conhecido dos intelectuais alemães tão aviltante proceder (Lobo, 29.01.1915).

Lobo denunciou as atrocidades cometidas pelos alemães na Bélgica e no norte da França, como saques e violação de mulheres. Conforme seu relato, as que não conseguiram fugir ficaram grávidas ou foram submetidas à servidão, sinal de que os militares alemães haviam "se comportado como verdadeiros animais":

Todos os atos de animalidade nas suas mais baixas e violentas manifestações foram cometidos, contribuindo ainda mais para envergonhar a geração atual, já sob o peso de tão grandes crimes (...) Esposas e filhas,

15 Sobre a missão médico-militar ver KROEFF, 1969.

16 LOBO, Bruno. A todas as senhoras brasileiras, sobretudo as que têm filhos. Jornal do Commercio (Rio de Janeiro), 24 fev. 1915. 
virgens e prostitutas foram todas assimiladas e confundidas pelos alemães, com instinto guerreiro saciado nas primeiras vitórias, mas com instinto genésico exaltado pelo repouso que se seguiu à luta e pela ação dos velhos vinhos das famosas caves da Bélgica e norte da França. Os fatos que se seguiram foram os mais tristes, os mais dolorosos e constituirão para sempre uma barreira para a paz e boas relações que devem existir entre os povos cultos e civilizados. As mulheres na sua maioria nada puderam fazer(...) Ficou bem claro que Louvain pagou com o incêndio e saque a ousadia de algumas mulheres pretenderem reagir contra o estupro!! (Lobo, 29.01.1915).

A preocupação de Lobo era com as consequências da gravidez indesejada: "Que fazer? Deixar que no seu ventre se desenvolva o fruto de tão grande infâmia?" indagou. Como reagiriam os esposos e pais das vítimas? Para Lobo era desconcertante que as mulheres violadas trouxessem em seu ventre "a herança dos maus institutos do seu gerador". Irônico, sugeriu que Rocha Lima consultasse os intelectuais alemães sobre o problema (Lobo, 29.01.1915).

O representante diplomático alemão em Porto Alegre verteu o artigo para o alemão e o enviou à chancelaria em Berlim como demonstrativo da aspereza da propaganda anti-germânica. ${ }^{17} \mathrm{~A}$ notícia foi enviada a Rocha Lima por um membro da colônia alemã do Rio de Janeiro de sobrenome Kastrup: "Queira desculpar a liberdade, mas o assunto é de tal gravidade para a reputação da Alemanha inteira, que eu não posso deixar de solicitar seu suporte". ${ }^{18}$ Da colônia alemã de Santa Catarina, Emilio Strauch também remeteu fragmento jornal com o texto de Lobo. ${ }^{19}$ Por estas cartas, dá para notar que o engajamento do pesquisador brasileiro em favor da Alemanha criou elos com a comunidade de teuto-brasileiros e de outros segmentos simpáticos às potências centrais. Mais um testemunho

17 PAAA 121944 Kaiserlich Deutsches Konsulat Porto Alegre am 23 abr. 1915.

18 Carta de J. Kastrup a Rocha Lima de 23 fev. 1915. Arquivo Rocha Lima, Centro de Memória do Instituto Biológico de São Paulo.

19 Carta de Emilio Strauch para Rocha Lima de 29 mar. 1915. Arquivo Rocha Lima, CMIBSP. 
disso é a manifestação de gratidão da Câmara de Comércio Brasil-Alemanha a Rocha Lima pelas “oportunas expressões" veiculadas no Jornal do Commercio. ${ }^{20}$ Isso porque a atuação de Rocha Lima atendia aos anseios da população de origem teuta de divulgar uma visão menos refratada pela propaganda pró-Aliada, missão à qual se dedicou a imprensa alemã no Brasil, mas com impacto limitado entre os "luso-brasileiros" (Luebke, 1987). Outra evidência é a carta da jornalista brasileira Lilia Emil-Wiesener, que trabalhava em Hamburgo como tradutora para o português do jornal Hamburger Nachrichten (Notícias de Hamburgo). Emil-Wiesener elogiou as argumentações de Rocha Lima e colocou o veículo no qual atuava à disposição para "expandir suas ideias". ${ }^{21} \mathrm{Tal}$ como ele, Emil-Wiesener trabalhou para o estreitamento das relações culturais entre Brasil e Alemanha. ${ }^{22}$

A réplica de Rocha Lima a Bruno Lobo veio a lume em maio de 1915, nas páginas do Diario Allemão, suplemento em português do jornal da colônia alemã de São Paulo, Deutsche Zeitung. ${ }^{23}$ Intitulado "O catedrático da calúnia”, o texto identifica a carta de Lobo com as circulares espalhadas pela França em reação à "bravura, heroísmo e resistência dos alemães nos combates”. Acuados, os franceses carregariam nas tintas na campanha de difamação e calúnia. "É a propaganda do medo, é o grito apavorado de quem se defende de trás de uma tocaia e tenta, quando se vê perdido, conquistar o auxílio de quem passa, chorando-lhe aos ouvidos e ao coração", atacou (Rocha Lima, 09.05.1915).

20 Carta da Câmara de Comércio Brasil-Alemanha a Rocha Lima de 23 dez. 1914. Arquivo Rocha Lima, CMIBSP.

21 Carta de Lilia Emil a Rocha Lima de 26 jan.1915. Arquivo Rocha Lima, CMIBSP.

22 Nos anos posteriores à Guerra, defendeu a criação de um instituto brasileiro em Hamburgo a funcionar como gabinete de leitura. O objetivo era promover nossa cultura entre os alemães, inclusive com a versão de textos para o idioma germânico e publicação de correspondências de notícias sobre o Brasil entre os jornais teutos. In: Um Instituto Brasileiro em Hamburgo. América Brasileira, anno I, jul. 1922.

23 ROCHA LIMA, Henrique da. O cathedratico da calumnia. Diario Allemão, Suplemento em Português do Deutsche Zeitung (São Paulo), 09 maio1915. 
Rocha Lima qualificou a Guerra como "cataclismo étnico" que opunha a raça latina à germânica, ou seja, como confronto de dois povos cuja formação étnica e histórica representavam valores opostos: a primeira, representante da civilização, das luzes, da razão e da justiça e a segunda, marcada pela barbárie; uma cultura da força, da cobiça, do autoritarismo e da irracionalidade. Este foi um mote bastante empregado pela propaganda Aliada, pois reafirmava os laços que uniriam latino-americanos e francesas pela ideia de uma "latinidade" comum (Compagnon, 2014). O pesquisador brasileiro subverteu tal retórica, positivando os valores da cultura alemã. Para ele, essa clara oposição evidenciada pela Guerra tornava impossível o indiferentismo: "Só os chimpanzés e os gorilas da África podem continuar a sua vida vegetativa sem um grito de horror e um olhar interessado. Do interesse do olhar, aos poucos, nasce a preferência" (Rocha Lima, 09.05.1915). Ele compreendeu o engajamento dos intelectuais e homens públicos como uma exigência das circunstâncias, que impossibilitavam a neutralidade. Justificou sua inclinação em favor da Alemanha pela rejeição das interferências inglesa - motivada por "desígnios cúpidos" - e russa - beijada "sem repugnância” pela França. Em adendo ao texto de Rocha Lima, o Diario Allemão elogiou a segurança e lógica apresentadas por ele no Jornal do Commercio, ao mesmo tempo em que denunciou as acusações infundadas de Bruno Lobo: "Não é um grave insulto aos vossos corações que alguém, catedrático ou não, apele para os vossos sentimentos para que patrocineis o aborto e o massacre de inocentes?" (Diario Allemão, 09.05.1915).

Os textos de Rocha Lima foram publicados até dezembro de 1914. Em 1915, veio a lume "Um ano de Guerra na Alemanha", no qual fez um balanço do conflito, animado pelo espírito de "conforto moral" que segundo ele reinava então na Alemanha: "É indescritível a sensação elevada de conforto moral de quem tem a felicidade de compreender e sentir a atmosfera de dedicação sem limites, de heroísmo estoico, de caridade sublime e desconfiança serena que há um ano e meio se respira na tão caluniada Alemanha" (Rocha Lima, s.d.). Tive acesso apenas à versão datilografada do texto depositada no acervo de Rocha Lima, sob a guarda do Centro de Memória do Instituto Biológico de São Paulo. 
Não foi possível verificar nem a data em que o escreveu, nem a de publicação na imprensa.

O texto do médico brasileiro traz justificativas que sugerem que as críticas ao seu posicionamento foram mais amplas do que a controvérsia com Bruno Lobo. Sublinhou que jamais afirmara que a Alemanha venceria ou deveria vencer a Guerra. Tampouco teria tentado convencer da vantagem desta vitória, demonstrado maior simpatia por aquele país do que por seus inimigos ou defendido que os brasileiros deveriam demonstrar inclinação pró-germânica. Por outro lado, reforçou a profunda admiração que sentia por aquele povo de "virtudes cívicas inexcedíveis", imposta como consequência da observação objetiva e "da lógica dos fatos" (Rocha Lima, s.d.):

Para um espírito reto e sereno a admiração é o produto de um julgamento objetivo e portanto imposto pela lógica dos fatos, o qual nada tem de comum com o sentimento quase subjetivo de simpatia. O moralmente forte pode admirar e odiar o mesmo indivíduo e não há dúvida que mesmo nos países que hoje combatem a Alemanha há muitos caracteres fortes que não negam admiração por este país que detestam. O contrário se dá com os que não conseguem ver senão através dos vidros turvos de suas inclinações, eles são tão fracos para fazerem justiça a um desafeto como para perceberem a natureza instintiva de suas afeições, sentem por isso necessidade de justificar suas paixões e apegam-se a tudo que para isso sirva sem indagar se é pura verdade ou a mais abominável das calúnias" (Rocha Lima, s.d.).

Rocha Lima negou que houvesse censura às informações estrangeiras na Alemanha. "Em nenhum país beligerante se facilita tanto a informação do povo sobre os acontecimentos da guerra como na Alemanha”, redarguiu, argumentando que dali tinha acesso a jornais de todo o mundo. Segundo ele os alemães acreditavam mais nos comunicados oficiais de seu governo porque eram os que se mostravam mais exatos (Rocha Lima, s.d.). 
A correspondência privada de Rocha Lima representou outro espaço de compartilhamento de opiniões pró-Alemanha. O médico Raul de Almeida de Magalhães, com quem havia estabelecido contato nos tempos em que atuara no Instituto de Manguinhos, ${ }^{24}$ transmitiu ao colega o deleite com a possível tomada de Varsóvia pelas tropas do Kaiser: "Os triunfos alemães têm desapontado alguns imbecis, que ainda supunham que as avalanches russas pudessem chegar até Berlim e que os cossacos pudessem amarrar seus cavalos nas tílias da Unter-den-Linden”. Magalhães inteirou Rocha Lima da atmosfera no Brasil. Segundo ele, a reação por parte dos simpáticos à Alemanha havia crescido, resultando na criação de uma Liga Pró-Germânica. ${ }^{25}$ Era uma resposta dos prógermânicos à Liga Brasileira pelos Aliados, fundada em 17 de março de 1915 e que reuniu entre seus quadros figuras de proa da intelectualidade local (Vinhosa, 1990, p.224; Compagnon, 2014). Magalhães deu conta do crescimento, na imprensa brasileira, da campanha contra o chamado "perigo alemão" - a ideia de que as comunidades de alemães no sul do país representavam uma ameaça à integridade nacional, na medida em que estariam sendo instiladas pelo expansionismo pangermânico do Reich, podendo tornar-se futuros alvos da investida imperialista de Guilherme II. ${ }^{26}$

A carta de Raul Magalhães é um dos poucos vestígios da rede epistolar mantida por Rocha Lima com brasileiros durante a Guerra. Ela sugere que o pesquisador do Instituto de Hamburgo não foi uma voz isolada. Em certa altura, ele se refere ao "grupo de amigos" aos quais

24 Raul de Almeida Magalhães compôs o grupo que frequentou o então Instituto Soroterápico de Manguinhos entre 1904 e 1907. Uma de suas primeiras contribuições científicas foi a identificação do agente causador da sífilis num feto natimorto. Foi um dos fundadores da Sociedade Brasileira de Higiene, diretor do Departamento de Saúde Pública no Distrito Federal e responsável pela elaboração do Regulamento Sanitário de Minas Gerais. Nomeado sanitarista por Gustavo Capanema em 1940.

25 Carta de Raul Almeida de Magalhães a Rocha Lima de 26 jul. 1915. Fundo Rocha Lima, Centro de Memória do Instituto Biológico de São Paulo.

26 Sobre o perigo alemão ver BRUNN, 1971; LUEBKE, 1987, p.70-76 e GERTZ, 1991. 
endereçava as cartas publicadas no Jornal do Commercio e as manifestações de apoio "que recebi de numerosos patrícios que ciosos da independência não só política como intelectual do Brasil não se julgam obrigados a odiar e insultar um povo que nenhum mal nos fez só porque ele se acha em guerra com a França e com a Inglaterra”, completou (Rocha Lima, 06.12.1914).

Carecemos de estudos que analisem o cenário intelectual do Brasil em termos de posicionamentos e alinhamentos na Grande Guerra, sobretudo no que se refere aos intelectuais germanófilos. Para o caso argentino, há o estudo de Maria Inés Tato (2012), que mostra que a identificação e simpatia cultural pela Alemanha foi bastante pronunciada entre militares, profissionais do direito, da medicina e das ciências naturais e exatas. Cabe recuperar alguns dos argumentos destes intelectuais argentinos a fim de compará-lo com os de Rocha Lima. Tal como o médico brasileiro, eles justificaram sua intervenção no espaço público pelo desconhecimento da Alemanha pela sociedade argentina, ainda mais mediante o monopólio da informação praticado pelos Aliados. Sentiram-se praticamente obrigados a combater a "conjuração do mundo" contra a Alemanha. Na opinião desses intelectuais, o Império Alemão fora empurrado para a Guerra para defender sua existência. A paz e não a Guerra era a condição para que os alemães seguissem sua trajetória de crescimento econômico e desenvolvimento. Dessa forma, recusavam a ideia de que estes eram os causadores do conflito e de que era um país bárbaro, autocrático e imperialista. Para eles imperialistas eram as atitudes dos Aliados (Tato, 2012, p.212).

$\mathrm{Na}$ mesma linha interpretativa de Rocha Lima, o jurista, linguista e historiador argentino Ernesto Quesada atribuiu a irrupção da Guerra à inquietação britânica diante do avanço comercial alemão, ao revanchismo francês interessado em recuperar os territórios perdidos da Alsácia-Lorena e ao pan-eslavismo russo, incitador dos nacionalismos que arriscavam a integridade do Império Austro-Húngaro (Tato, 2012, p.212).

As intervenções de Rocha Lima em favor da Alemanha encerraram-se com o texto "Um ano de Guerra na Alemanha", de 1915 (Rocha Lima, 
s.d.). ${ }^{27}$ Não são claras as razões da interrupção da publicação de seus textos. Elas podem estar ligadas a circunstâncias de sua trajetória individual e/ou da própria imprensa no período, basicamente, do Jornal do Commercio. Como já dito, o periódico aprofundou seu posicionamento em favor dos Aliados, inclusive publicando regularmente os boletins da Liga Brasileira pelos Aliados. Nesse momento é possível que já não houvesse espaço para uma coluna tão manifestamente pró-germânica como a de Rocha Lima. Tornou-se ainda mais difícil quando o Brasil declarou Guerra à Alemanha em $1917 .{ }^{28}$ Em dezembro de 1914, o médico brasileiro disse estar escasso o tempo para escrever a correspondência devido à chegada de número crescente de feridos, o que sugere que ficou encarregado da assistência aos oficiais em Hamburgo (Rocha Lima, 06.12.1914). A Guerra fez com que se adaptassem as dependências do Instituto de Doenças Tropicais para servirem como hospital militar. Os pesquisadores que como Rocha Lima não haviam sido recrutados foram mobilizados para atender os feridos (Manweiler, 1998). Em 1915, Rocha Lima aprofundou os estudos experimentais sobre o tifo exantemático. No ano seguinte, dedicou-se com afinco à divulgação do agente que incriminara como causador da doença. Publicou mais de vinte artigos na imprensa médica alemã em 1916, num esforço não só de garantir o reconhecimento do microrganismo por ele descrito, como também de defender sua prioridade naquele feito (Silva, 2011). Concentrado em conquistar seu lugar no front científico, deixou de lado a batalha na opinião pública brasileira. A entrada do Brasil na Guerra ao lado dos Aliados em 1917 certamente comprometeu a situação do pesquisador brasileiro na Alemanha. A participação do país no conflito foi consequência de uma progressiva aproximação com os norte-americanos e pela pressão de setores pró-aliados. Estas se intensificaram e dificultaram a posição de neutralidade sobretudo depois do afundamento de

27 A data é suposta em função do título do texto, mas não consegui identificar a data de publicação no Jornal do Commercio, conforme mencionado anteriormente.

28 Sobre o impacto da Guerra entre as comunidades e associações teuto-brasileiras ver LUEBKE, 1987. 
navios brasileiros pelos alemães em 1917, um capítulo da guerra submarina travada por estes. ${ }^{29}$ É bem possível que esta foi uma das razões pelas quais Rocha Lima permaneceu realizando pesquisas no território polonês, então administrado por um governo de ocupação alemã.

A germanofilia permaneceu um traço marcante de Rocha Lima. Nos anos posteriores à Guerra, ela pautou sua atuação em favor da diplomacia cultural posta em ação pelos alemães (Silva, 2013). O Tratado de Paz, assinado em Versalhes, impôs condições severas aos derrotados. No plano da política externa, a dimensão cultural foi uma das poucas não afetadas pelas restrições do Tratado (Düwell, 1981, p.46-47; Rinke, 1996, p.413; Gliech, 2003, p.21). A experiência do conflito ensinara-lhes a importância dos nichos de simpatia cultural no eventual enfrentamento entre os países europeus. Viram o quanto estavam defasados em relação à azeitada máquina de diplomacia cultural montada pelos franceses. Segundo Stefan Rinke (1996, p.414), a percepção de que faltava uma política cultural externa coordenada e sistemática levou, entre outras coisas, à criação do Instituto Ibero-Americano de Hamburgo, em $1917 .{ }^{30}$ As ações de propaganda durante a Guerra evidenciaram também a importância de se conquistar influência na imprensa, tornando esta uma importante estratégia da política para a América Latina nos anos seguintes (Rinke, 1996, p.489-492).

Rocha Lima foi um parceiro importante da diplomacia e de outros atores alemães no esforço de conquistar a simpatia cultural das elites brasileiras, principalmente entre os médicos e cientistas. Nestes segmentos estiveram os mais entusiasmados pontos de apoio da política cultural germânica (Silva, 2013). Em 1920, antes mesmo que as representações diplomáticas estivessem reocupadas, o neurocirurgião Fedor Krause foi recebido nas instituições médicas e culturais brasileiras. Sua

29 Em abril de 1917 foi afundado o navio Paraná, em maio o Tijuca e Lapa e em outubro o Guaíba e Acari. As relações comerciais foram rompidas em fevereiro daquele ano e as diplomáticas em abril. A declaração de guerra veio em 26 de outubro de 1917. Sobre a entrada do Brasil na Primeira Guerra ver LUEBKE, 1987; VINHOSA, 1990 e COZZA, 1996.

30 Sobre o Instituto Ibero-Americano nesse contexto ver SETTEKORN, 1990. 
estadia coincidiu com a de Rocha Lima. Segundo este, ao desembarcar no Rio de Janeiro em 1920, encontrara um ambiente "favorável à Alemanha", ainda que observasse "vestígios de ânimos acirrados por causa da guerra". ${ }^{11} \mathrm{O}$ conhecimento do meio local e seu renome entre os pares permitiram-lhe articular a recepção de Krause. A boa acolhida do cirurgião foi interpretada pela diplomacia alemã como um sinal de que os brasileiros não tinham "prevenção à Alemanha e seus filhos". ${ }^{32}$ Através da política cultural procurava-se pôr panos quentes nos conflitos que envolveram os teuto-brasileiros durante a Guerra. ${ }^{33}$

A promoção da cultura e ciência alemãs nos meios científicos e culturais brasileiros tornou-se uma constante na trajetória de Rocha Lima. Se a Primeira Guerra foi quando pronunciou-se pela primeira vez em favor da Alemanha, dali por diante a identificação e a defesa daquele país foram frequentes, mesmo depois dele retornar ao Brasil, em 1927. As consequências dessa identificação repercutiram nas representações em torno de sua trajetória e de sua memória.

\section{CONSIDERAÇÕES FINAIS}

Rocha Lima relatou sobre o inicio da Guerra num momento de movimentos dinâmicos de tropas entre os territórios. A rápida movimentação e as conquistas do exército alemão haviam deixado os aliados na defensiva. Tempos depois, tal dinamismo daria lugar, no front ocidental, ao impasse da chamada "guerra de trincheiras", na qual os exércitos inimigos encontraram-se paralisados, enfrentando-se numa luta contínua e mortífera. Nesse período, o médico brasileiro dedicava-se a suas

31 Rocha Lima, Henrique da. Bericht ueber die Reisen von Prof. Rocha Lima nach Brasilien 1920, 1922 (Datilografado). Arquivo Rocha Lima, Centro de Memória do Instituto Biológico de São Paulo, São Paulo.

32 Arquivo Histórico do Itamaraty.Telegrama recebido do Ministério das Relações Exteriores em 03 ago. 1920, Notação 203/1/08 - 1922-23.

33 Sobre esses conflitos ver LUEBKE, 1987. 
pesquisas sobre o tifo exantemático e à doença emblematicamente conhecida como "febre das trincheiras".

O posicionamento de Rocha Lima contrastou com a aliadofilia que magnetizou a maior parte dos intelectuais latino-americanos (Compagnon, 2014). O fato de viver na Alemanha e de ter notícias em primeira mão sobre o decorrer da Guerra segundo ele habilitavam-no a fornecer aos seus compatriotas visão independente daquelas veiculadas pelas agências de notícias francesa e inglesa. As notícias que abasteceram o patologista brasileiro provinham em grande parte de uma imprensa submetida à censura imposta pelo estado de sítio, embora ele não reconhecesse. Os jornais foram componentes fundamentais da engrenagem de propaganda direcionada à sociedade alemã, com o objetivo de criar um consenso em torno do conflito. No primeiro ano da guerra várias diretrizes e órgãos foram implementados para regulamentar a dinâmica e os parâmetros da propaganda. A retórica apelou para os supostos valores tradicionais de obediência, dever e patriotismo. Apesar disso, houve espaço para a discussão sobre os objetivos da guerra e reformas políticas (Welch, 2000, p.6-7).

Os argumentos mobilizados pelo cientista refletem o discurso da propaganda oficial alemã. Apesar da censura e do controle previsto pelos órgãos de propaganda, na Alemanha houve maior tolerância em termos de acesso à imprensa dos países neutros se comparado com França e Inglaterra. Os jornais alemães foram autorizados a imprimir os relatórios de guerra dos oponentes e divulgaram as críticas ao governo feitas no parlamento (Welch, 2000, p.40). Esse aspecto foi apontado por Rocha Lima em seus textos, como uma forma de comprovar que no Reich havia maior comprometimento com a verdade do que nos países inimigos.

Podemos considerar esse personagem um dos elos da cadeia de informações acionada pela propaganda alemã. Ele ligou diretamente a "fonte" de discursos com o público brasileiro, assim driblando as restrições estruturais e socioculturais que limitaram a ação dessa propaganda no Brasil. Muito embora não tenha atuado como agente dos órgãos oficiais de propaganda, certamente Rocha Lima contribuiu para 
disseminar entre os brasileiros os principais argumentos por eles veiculados nos fronts interno e externo. Fica para analisar o impacto desta ação entre as instâncias envolvidas com tal propaganda para o Brasil.

O desconhecimento do caráter alemão, segundo Rocha Lima, seria produto da hegemonia da cultura francesa entre as nossas elites, o que para ele tornava-nos míopes e meros "clientes" das investidas de propaganda dos Aliados. Seus argumentos em grande medida estão em sintonia com os defendidos pela intelligentsia alemã, convulsionada pelo "espírito de 1914" e por outros personagens identificados, por razões diversas, com a cultura germânica, como Tato (2012) demonstra para o caso argentino.

Conforme aponta Codera (2013), depois da Guerra os intelectuais não voltariam a ter um comportamento intelectual autônomo e singular: "O conflito converteu-se num guia de leitura imprescindível para definir suas posturas futuras tanto a nível social quanto nacional durante as décadas seguintes" (Codera, 2013, p.1). O "patriotismo militante" de muitos desses intelectuais repercutiu negativamente, reverberando tal percepção nos anos 1920, quando ganhou força a ideia de que eles haviam traído a sociedade. Expressão disso foi a obra de Julien Benda publicada em 1927 “A traição dos intelectuais” (Prochasson, 2010, p.323). No caso de Rocha Lima, o engajamento durante a Guerra foi o ponto de partida de um perfil de atuação no espaço público brasileiro e alemão nas décadas seguintes. Foi produto de sua convicção pessoal da excelência do "caráter" alemão. Para ele, o conhecimento e aproximação com aquela cultura possibilitaria ao Brasil diversificar suas fontes de inspiração intelectual, abandonando a posição de simples consumidor de ideias geradas alhures. Tal convicção converteu-o num dos mais ativos promotores das relações culturais e científicas entre Brasil e Alemanha, tornando este um traço marcante de sua trajetória profissional.

\section{Agradecimentos}

Fundação de Amparo à Pesquisa do Estado de São Paulo (FAPESP); Instituto Biológico de São Paulo. 


\section{REFERÊNCIAS BIBLIOGRÁFICAS}

BENCHIMOL, Jaime Larry. Beziehungen zwischen Brasilien und der deutschsprachigen Welt in Wissenschaft und Medizin, 1850-1918. In: FISCHER, Georg; PETERS, Christina; RINKE, Stefan; SCHULZE, Frederik (org.). Brasilien in der Welt. Region, Nation und Globalisierung 18701945. Frankfurt am Main: Campus, 2013. p.243-270.

BENCHIMOL, Jaime Larry. Manguinhos do sonho à vida: A ciência na Belle Epoque. Rio de Janeiro: Editora Fiocruz, 1990.

BRUNN, Gerhard. Deutschland und Brasilien, 1889-1914. Köln and Wien: Bohlau-Verlag, 1971.

CLARK, Christopher. Os sonâmbulos: como eclodiu a Primeira Guerra Mundial. São Paulo: Companhia das Letras, 2014.

CODERA, Maximiliano Fuentes. Presentación Dossier La Gran Guerra de los Intelectuales: España en Europa. Ayer - Revista de Historia Contemporánea, vol. 91, n. 3, p.13-31, 2013.

COMPAGNON, Olivier. O adeus à Europa: a América Latina e a Grande Guerra. Rio de Janeiro: Rocco, 2014.

COZZA, Dino Willy. A participação do Brasil na Primeira Guerra Mundial. Revista do Instituto Histórico e Geográfico Brasileiro, ano 157, n. 390, p.97-110, 1996.

DÜWELL, Kurt. Die Gründung der Kulturpolitischen Abteilung im Auswärtigen Amt 1919/20 als Neuansatz. Inhaltliche und organisatorische Strukturen der Reform auswärtiger Kulturpolitik nach dem Ersten Weltkrieg. In: DÜWELL, Kurt; LINK, Werner (Hg.). Deutsche auswärtige Kulturpolitik seit 1871. Geschichte und Struktur. Referate und Diskussionen eines interdisziplinären Symposiums. Köln and Wien: Böhlau, 1981. p.46-61.

ECKART, Wolfgang. Medizin und Krieg: Deutschland 1914-1924. Paderborn: Ferdinand Schöningh Verlag, 2014.

GARAMBONE, Sidney. A Primeira Guerra Mundial e a Imprensa Brasileira. Rio de Janeiro: Mauad, 2003.

GERTZ, René. O perigo alemão. Porto Alegre: Editora da UFRGS, 1991.

GLIECH, Oliver. Lateinamerikanische "Multiplikatoren” im Visier. Kulturpolitische Konzeptionen für das Ibero-Amerikanische Institut zum 
Zeitpunkt seiner Gründung. In: LIEHR, Reinhard; MAIHOLD, Günther; VOLLMER, Gunther. Ein Institut und sein General: Wilhelm Faupel und das Ibero-Amerikanische Institut in der Zeit des Nationalsozialismus. Frankfurt: Vervuert, 2003. p.17-66.

HEROLD, Heiko. Deutsche Kolonial- und Wirtschaftspolitik in China 1840 bis 1914. Unter besonderer Berücksichtigung der Marinekolonie Kiautschou. Auflage: Köln, 2006.

HEWITSON, Mark. Germany and the Causes oft he First World War. Oxford and New York: Berg, 2004. (The Legacy of the World War)

HORNE, John; KRAMER, Alan. Deutsche Kriegsgreuel, 1914. Die umstrittene Wahrheit. Hamburgo: Hamburger Edition, 2004.

JONES, Heather. As the Centenary Approaches: the Regeneration of First World War Historiography. The Historical Journal, vol. 56, n. 3, p.857878, 2013.

KEIGER, John F. V. The War Explained: 1914 to Present. In: HORNE, John (ed.). A Companion to World War I. London: Wiley-Blackwell, 2010. p.19-31. (Blackwell Companions to World History)

KROEFF, Mário. Missão Médica Militar em França na Guerra de 1918. O Hospital, vol. 75, n. 2, p.405-423, 1969.

KRUMEICH, Gerd. The War Imagined: 1890-1914. In: HORNE, John (ed.). A Companion to World War I. London: Wiley-Blackwell, 2010. p.3-18. (Blackwell Companions to World History)

LUEBKE, Frederick Carl. Germans in Brazil: a Comparative History of Cultural Conflict during World War One. London: Louisiana State University Press, 1987.

MANNWEILER, Erich. Geschichte des Instituts für Schiffs- und Tropenkrankheiten in Hamburg, 1900-1945. Keltern-Weiler: Goecke und Evers, 1998. MOMBAUER, Annika. The Origins of the First World War: Controversies and Consensus. Londres: Longman, 2002.

PROCHASSON, Christophe. Intellectuals and Writers. In: HORNE, John (ed.). A Companion to World War I. London: Wiley-Blackwell, 2010. p.323-337. RINKE, Stefan. Der letzte freie Kontinent: Deutsche Lateinamerikapolitik im Zeichen transnationaler Beziehungen, 1918-1933. Stuttgart: Heinz, 1996. 
RÜGER, Jans. The great naval game: Britain and Germany in the age of empire. Cambridge: Cambridge University Press, 2007.

SÁ, Magali Romero. The history of Tropical Medicine in Brazil: the Discovery of Trypanosoma cruzi by Carlos Chagas and the German School of Protozoology. Parassitologia, vol. 47, p.309-317, 2005.

SCHROEDER-GUDEHUS, Brigitte. Challenges to Transnational Loyalties: International Scientific Organizations after the First World War. Science Studies, vol. 3, n. 2, p.93-118, 1973.

SELIGMANN, Matthew; MCLEAN, Roderick R. Germany from Reich to Republic: Politics, Hierarchy and Elites. Basingstoke and London: Palgrave MacMillan, 2000.

SETTEKORN, Wolfgang. Die frühe Hamburger Iberoamerikanistik und der Krieg. Andere Aspekte romanistischer Fachgeschichte. Iberoamericana, vol. 1, n. 14, p.33-94, 1990.

SILVA, André Felipe Cândido da. A trajetória científica de Henrique da Rocha Lima e as relações Brasil-Alemanha (1901-1956). Tese (Doutorado em História das Ciências e da Saúde) - Casa de Oswaldo Cruz, Fiocruz. Rio de Janeiro, 2011.

SILVA, André Felipe Cândido da. The scientist-diplomat: Henrique da Rocha Lima and the German-Brazilian relations, 1919-1927. Jahrbuch für Geschichte Lateinamerikas, vol. 50, p.261-288, 2013.

STERN, Fritz. O mundo alemão de Einstein. São Paulo: Companhia das Letras, 2004.

TATO, Maria Inés. Contra la corriente. Los intelectuales germanofilos argentinos frente a la Primera Guerra Mundial. Jahrbuch für Geschichte Lateinamerikas, vol. 49, p.205-223, 2012.

THER, Vanessa. Propaganda at Home (Germany). In: DANIEL, Ute et al. 1914-1918-online. International Encyclopedia of the First World War. Berlim: Freie Universität, 2014. Disponível em: http://encyclopedia.19141918-online.net/article/propaganda_at_home_germany; Acesso em: 05 maio 2015.

UNGER-STERNBERG, Jürgen; UNGER-STERNBERG, Wolfgang. Der Aufruf "An die Kulturwelt!": Das Manifest der 93 und die Anfänge der Kriegspropaganda im Ersten Weltkrieg. Steiner: Stuttgart, 1996. 
VINHOSA, Francisco Luiz Teixeira. O Brasil e a Primeira Guerra Mundial: a diplomacia brasileira e as grandes potências. Rio de Janeiro: Editora do IHGB, 1990.

WELCH, David. Germany, Propaganda and Total War, 1914-1918. New Brunswick and New Jersey: Rutgers University Press, 2000.

WINTER, Jay; PROST, Antoine. The Great War in History: Debates and Controversies, 1914 to the Present. Cambridge: Cambridge University Press, 2005. 